\title{
Parentesco, autoridad cacical y subordinación al orden. Una revisión teórica e histórica de la política rosista hacia las parcialidades "amigas" de la región pampeana (Buenos Aires, 1829-1839)1/
}

Kinship, chiefly Authority and Subordination to the Order. A theoretical and historical Revision of Rosas Politics towards "friendly" Moieties in Pampa Region (Buenos Aires, 1829-1839)

María Laura Cutrera y Ariel J. Morrone

Universidad de San Andrés / CONICET

y Universidad de Buenos Aires, Argentina

En el marco de la renovación historiográfica en torno al estudio de las sociedades indígenas y de frontera pampeano-patagónicas, la autoridad cacical ha sido uno de los tópicos más polémicos, dado el disenso a la hora de caracterizar sus estructuras sociopolíticas. Este artículo propone revisar los marcos conceptuales heredados, esbozar nuevas líneas de análisis teórico y sugerir nuevos conceptos que nos permitan repensar el "Negocio Pacífico de Indios", que ha trascendido en la historiografía como la política específica del gobierno rosista para subordinar a las parcialidades “amigas”.

Palabras Clave: Parentesco; Jefatura inducida; Subordinación; Orden provincial.

Within the historiographical renovation regarding the study of Pampa and Patagonia's indigenous and frontier societies, chiefly authority has been one of the most polemic issues, due to the disagreement when characterizing their sociopolitical structures. This article proposes to revise inherited conceptual frames, to outline new theoretical lines of analysis and to suggest new concepts which allow us to rethink the "Negocio Pacífico de Indios", which has transcended in historiography as the specific politic of Rosas government in order to subordinate "friendly" moieties.

KEYwords: Kinship; Inducted chiefdom; Subordination; Provincial order.

Sólo hay que pedir a cada uno, lo que cada uno puede dar-continuó el rey. La autoridad se apoya antes que nada en la razón. (...) Yo tengo derecho a exigir obediencia, porque mis órdenes son razonables. (...) Tendrás tu puesta de sol. La exigiré. (...) será hacia las siete cuarenta. Rey del Asteroide 325, Antoine de Saint-Exupéry, El Principito, cap. X

1 Una versión preliminar de este trabajo fue presentada en las XI Jornadas Interescuelas/Departamentos de Historia, Tucumán (Argentina), 19 al 22 de septiembre de 2007. Agradecemos los agudos comentarios que en esa oportunidad nos hiciera la doctora Marcela Tamagnini, como así también la lectura crítica de la doctora Martha Bechis y del doctor Jorge Gelman. 


\section{Puntos de partida históricos, historiográficos y teóricos del problema}

Desde mediados de la década de 1810 y durante gran parte del decenio siguiente, las parcialidades nativas que habitaban el sur del actual territorio bonaerense se vieron asediadas por el avance de dos frentes conflictivos. Por un lado, el asentamiento en dicho territorio de pobladores criollos se venía consolidando desde fines del siglo XVIII. Para entonces, el río Salado oficiaba como barrera natural entre los grupos indígenas de la pampa y las poblaciones hispanocriollas. Pero si bien ese borde de ocupación se mantuvo hasta entrada la década de 1820 , su presencia no impidió que los habitantes de Buenos Aires se derramaran más allá, internándose en territorio indígena a su propio riesgo y merced a las negociaciones que establecían con los aborígenes, así como tampoco el paso de éstos a la capital provincial para establecer relaciones de intercambio o diplomacia. ${ }^{2}$

Por otra parte, como consecuencia de la prolongación al este de la Cordillera de los Andes de los conflictos independentistas chilenos, tuvo lugar el ingreso de contingentes de esa procedencia que incluían tanto grupos realistas de indios, criollos, mestizos, soldados y bandoleros, como alianzas patriotas de similar composición que los perseguían. ${ }^{3}$ La presión por los recursos, principalmente el ganado, se sumó a las contiendas políticas de esos años, dando lugar a una seguidilla de malones y contraataques hacia y desde la frontera bonaerense que incrementaron el nivel de tensión e inestabilidad existente en la campaña. ${ }^{4}$ Estas circunstancias obligaron a

2 Para un panorama general del problema de las relaciones interétnicas en el siglo XVIII, véase Néspolo, Eugenia A.: Resistencia y complementariedad, Gobernar en Buenos Aires. Luján en el siglo XVIII: un espacio políticamente concertado, Tesis de Doctorado en Historia, Facultad de Filosofía y Letras, Universidad de Buenos Aires, diciembre de 2006. Sobre los conflictos y la inestable situación de la frontera bonaerense a partir de mediados de la década de 1810, ver Bechis, Martha A.: "De hermanos a enemigos: los comienzos del conflicto entre los criollos republicanos y los aborígenes del área arauco-pampeana, 1814-1818”, en Bandieri, Susana O. (coord.): Cruzando la Cordillera... La frontera argentino-chilena como espacio social, CEHiR-UNCo, Neuquén, 2001, págs. 65-99.

3 Sobre la llamada "Guerra a Muerte" y sus dos fases, "cordillerana" y "pampeana", ver Villar, Daniel y Jiménez, Juan Francisco: "La tempestad de la guerra: conflictos indígenas y circuitos de intercambio. Elementos para una periodización (Araucanía y las pampas, 1780-1840)”, en Mandrini, Raúl J. y Paz, Carlos D. (comps.): Las Fronteras Hispanocriollas del Mundo Indígena Latinoamericano en los Siglos XVIII-XIX. Un estudio comparativo, IHES-UNCPBA / CEHIR-UNCo / UNSur, Tandil, 2003, págs. 123-171.

4 Merecen destacarse, en este sentido, el malón de 1820 sobre el pueblo de Salto y las campañas llevadas a cabo por las autoridades de Buenos Aires. Las primeras tuvieron lugar en 1821, 1822 y 1823, bajo el mando del entonces gobernador Martín Rodríguez. Durante el transcurso de la última se fundó el fuerte Independencia (actual Tandil), materializando la ocupación oficial varias leguas al 
las autoridades porteñas a tener siempre en cuenta la existencia de vecinos sureños más o menos propensos a la negociación. A su vez, las parcialidades nativas más próximas se descubrieron atrapadas en un movimiento de tenazas desplegado desde el norte y el oeste.

Cuando la guerra con Brasil hizo real la posibilidad de una invasión portuguesa en las costas meridionales de la provincia, la necesidad de ganar la buena voluntad de los indígenas se volvió impostergable. Fue así que primaron las intenciones de establecer algún tipo de acercamiento y acuerdo con ellos y asegurar el espacio ocupado hacia el sur. En 1826, el gobernador Gregorio Las Heras comisionó al comandante de milicias de campaña de la provincia, Juan Manuel de Rosas, para formalizar un tratado de paz, tranquilizar los ánimos y estudiar por dónde correría la nueva línea de frontera, tarea que Rosas compartió con Felipe Senillosa y Juan Lavalle. ${ }^{5}$ El resultado de la empresa fue el establecimiento de un acuerdo con los aborígenes, en el que se sentaron las bases de una política de paz tendiente a prolongarse durante casi treinta años, asociada comúnmente con el rosismo y popularizada como "Negocio Pacífico de Indios".

El "Negocio Pacífico de Indios", tal como Rosas pareció entenderlo, fue una elaborada, compleja y constante negociación que buscaba establecer y sostener una conveniente relación de "amistad" con los grupos nativos. Asumió formas prácticas que variaron en función de la especificidad de las coyunturas atravesadas. Si su expresión concreta fueron prolongados parlamentos e intercambios verbales, también la entrega de regalos y raciones formó parte misma de la dinámica del pacto. ${ }^{6}$ Como resultado de esta política, nutridos contingentes indígenas se incorporaron al territorio de la provincia. Los grupos que respondían a la autoridad de los caciques Juan

sur de la línea establecida durante el periodo colonial y violando parte de lo dispuesto por el Tratado de Miraflores -importante acuerdo con la población nativa- firmado el 7 de marzo de 1820 . En él se disponía, entre otras cosas, que los criollos no avanzarían más allá de las últimas estancias, esto es, sólo un poco más al sur del río Salado.

5 Comando en Jefe del Ejército (Dirección de Estudios Históricos): Política Seguida con el Aborigen, Biblioteca del Oficial, Buenos Aires, 1974, vol. 2.

6 Silvia Ratto asocia el Negocio Pacífico con la circulación de bienes y animales desde Buenos Aires hacia las sociedades indígenas, o con la red de autoridades dispuesta para el cuidado y atención de dicha circulación. Véase Ratto, Silvia M.: "Indios Amigos e Indios Aliados. Orígenes del Negocio Pacífico en la provincia de Buenos Aires (1829-1832)", Cuadernos del Instituto de Historia Argentina y Americana "Dr. Emilio Ravignani”, FFyL-UBA, núm. 5, 1994; y "El 'negocio pacífico de los indios': la frontera bonaerense durante el gobierno de Rosas”, Siglo XIX, 15, México, 1994, págs. 25-47. Si bien el Negocio Pacífico pudo tener traducciones materiales efectivas, no puede confundirse con ellas. Se trató, ante todo, de un modo muy complejo de hacer política, que puso en juego algunas herramientas de negociación que aparecerán más adelante en este trabajo. 
Catriel y Juan Manuel Cachul se instalaron en las estancias propiedad de (o administradas por) Rosas, y fueron relocalizados en los fuertes fronterizos en 1832. A partir de entonces, y por razones de defensa de una ocupación criolla prolongada varias leguas hacia el sur, se situaron en las proximidades del cantón de Tapalqué y del fuerte San Serapio Mártir del Arroyo Azul. Entre tanto, desde mediados de la década del veinte varias parcialidades se ubicaron en los alrededores del fuerte Independencia, respondiendo de forma inmediata a los caciques Anteguan, Maicá y Petí, seguidores de Catriel y Cachul. Otros, al mando de Venancio Koñwepan, se establecieron en las inmediaciones de Bahía Blanca. Al mismo tiempo, el gobierno provincial desplegó la agresión sobre los grupos que no se dispusieran a acercarse a Buenos Aires en los términos propuestos por Rosas.

En trabajos anteriores hemos planteado que la ubicación de los llamados "indios amigos" dentro del espacio ocupado por la provincia, implicó su debida sujeción al orden que el gobierno quería asegurar, particularmente en la campaña. Para lograrlo, se pusieron en juego un dispositivo de autoridades que involucró al mismo Rosas - como gobernador-en la cúspide; al comandante del fuerte de Monte y su amigo personal, Vicente González; a los comandantes de los fuertes rodeados de tolderías indígenas (Bernardo Echevarría en Tapalqué, Francisco Serantes, Manuel Capdevila y Pedro Rosas y Belgrano en Azul, y Pablo Muñoz en Tandil); y a los caciques Catriel, Cachul y Koñwepan. En ellos se ataba el nudo de poder local. Así, las autoridades fronterizas e indígenas se vieron expuestas a una situación particular y por demás contradictoria, generada por la necesidad de recibir, traducir y asegurar el cumplimiento de las disposiciones emanadas de Buenos Aires. ${ }^{7}$ Esta involucraba especialmente a los primeros en su interacción con los caciques, y a ellos con sus respectivos seguidores.

El tipo de vínculo planteado inauguró espacios de intermediación política, "espacios mesopolíticos" de traducción de discursos y prácticas. Por espacio mesopolítico entendemos a las instancias de intercesión (teóricas, no materiales) habilitadas por el contacto entre sociedades estatales expansivas y otras no estatales, sobre las que las primeras se proyectan. No se trata de una región geográfica específica; es más bien un ámbito de interacción social, que toma encarnadura en situaciones históricas concretas que hacen posible el establecimiento, reproducción y consolidación de un tipo

7 Cutrera, María Laura: "Subordinarlos", “someterlos” y "sujetarlos al orden”. Los indios amigos de Azul, Tandil y Tapalqué en la década de 1830, Tesis de Maestría en Investigación Histórica, Universidad de San Andrés, Buenos Aires, febrero de 2006. 


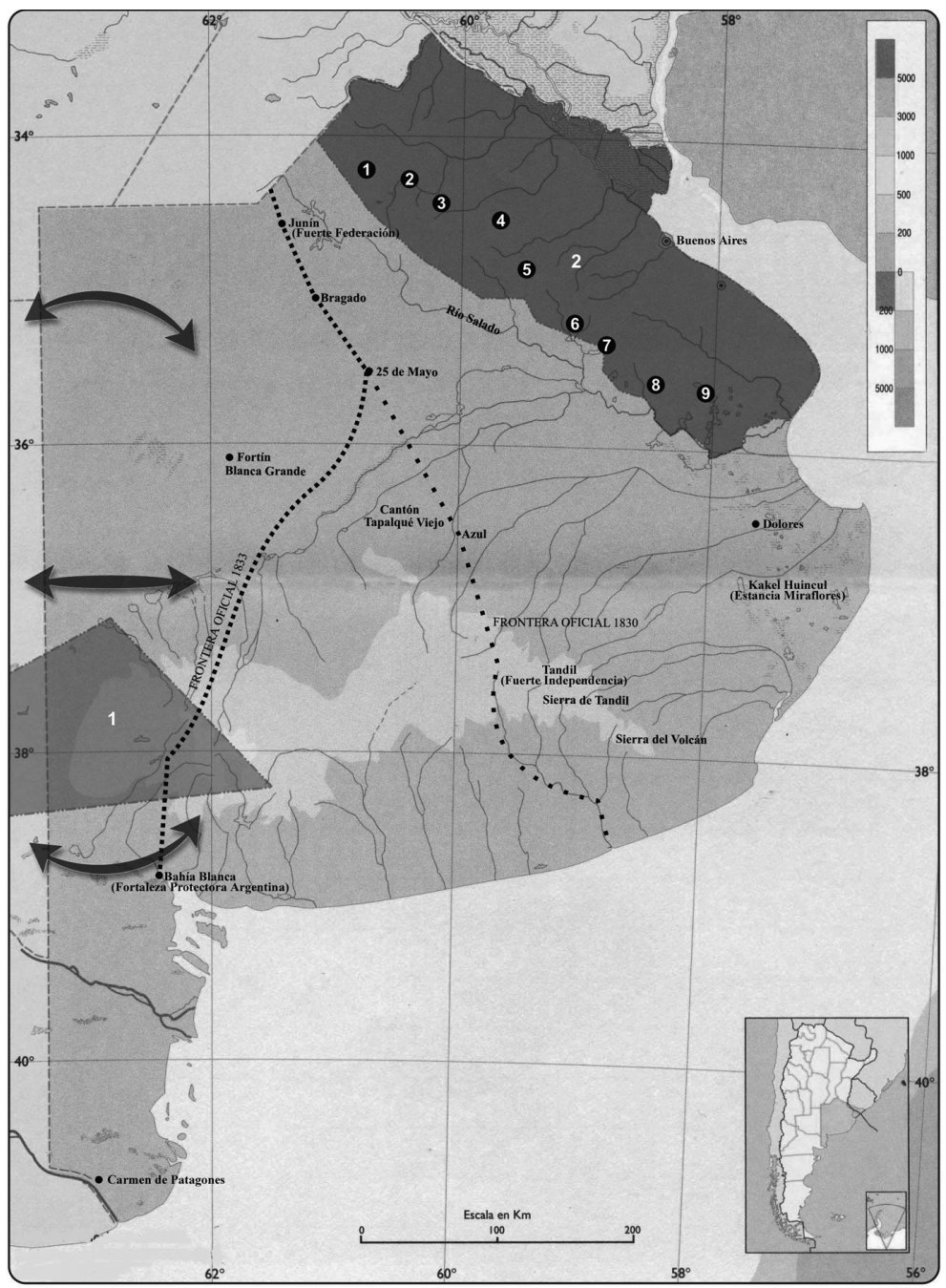

Referencias

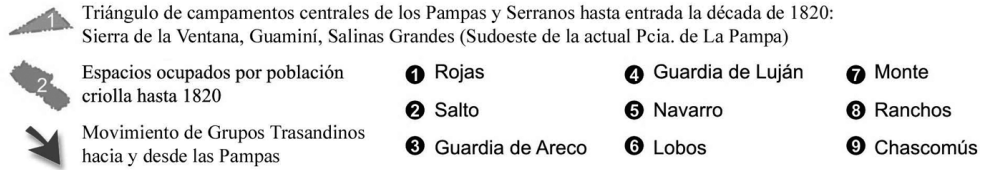

La frontera bonaerense durante las décadas centrales del siglo XIX.

Principales referencias mencionadas en el trabajo. Elaboración de los autores. 
indirecto de gobierno. ${ }^{8}$ Dicho espacio funcionó como "válvula de traducción", toda vez que el conjunto de participantes tuvo que encontrar las maneras de hacer inteligibles exigencias y consideraciones que, a pesar de los siglos de contacto interétnico, no habían sido sumidas en ningún mestizaje ni proceso sincrético. A su turno, los caciques debieron retornar a sus comunidades de origen, transmitir y resignificar aquellos mensajes (discursivos y materiales) originados en la sociedad criolla, y luego diseñar sus propias estrategias de acción en base a la experiencia acumulada y a la creatividad disponible.

Ubicados en esa posición de intermediación, los caciques tuvieron que cumplir con las obligaciones impuestas por las autoridades y por el colectivo social al que de alguna manera representaban ante aquellas. Para ello debieron dar a conocer las exigencias de las primeras en un lenguaje entendible y acorde a la lógica colectiva cifrada en términos parentales procurando, al mismo tiempo, no exceder los límites que esa lógica les imponía en tanto líderes. ${ }^{9}$

8 Morrone, Ariel J.: "La autoridad cacical en las sociedades indígenas de la región pampeana (siglos XVI-XIX). Algunas consideraciones teórico-historiográficas” [2003], en Miradas al Pasado desde Chivilcoy, publicación en CD editada por el Centro de Estudios en Ciencias Sociales y Naturales, Chivilcoy, 2004, págs. 746-763.

9 La relativa ausencia de referencias al parentesco en los análisis sobre la autoridad cacical entre los grupos nativos de la región pampeana y sobre las relaciones interétnicas en la frontera bonaerense hace que, por momentos, perdamos de vista el impacto efectivo que tuvo la incorporación al territorio provincial en el interior de las parcialidades "amigas". Contadas son las excepciones que conocemos: el trabajo clásico de Faron, Louis C.: "Araucanian Patri-organization and the Omaha System", American Anthropologist, 58, 1956, págs. 435-456; dos trabajos de Bechis, Martha A.: "Matrimonio y política en la génesis de dos parcialidades Mapuche durante el siglo XIX", Memoria Americana,3, Buenos Aires, 1994, págs. 41-62; y "Repensando la sucesión Yanquetruz-Painé-Calbán: una contribución a la destrivialización de la historia ranquelina", en Poduje, M. (coord.): Memorias de las III Jornadas de Historia y Cultura Ranquelina, Departamento de Investigaciones Culturales, Santa Rosa, 1998, págs. 181-193; y uno reciente de Jiménez, Juan Francisco: Matrilinealidad versus Patrilinealidad. La obra de Félix José de Augusta y la polémica acerca de la filiación entre los rechemapuche, UNSur, Bahía Blanca, 2002. Lo expuesto cobra particular importancia si tenemos en cuenta que el parentesco era la lógica, la práctica que organizaba las sociedades aborígenes. Que éste resultase la práctica dominante significa, en términos de Racdlife Brown, que los vínculos entre las personas se trazaban a través de relaciones de consanguinidad/afinidad y que las conductas y actitudes de quienes así se ligaban eran influidas por estos lazos, tanto como por los usos y costumbres colectivas. A su vez, el parentesco crea e incluye grupos sociales definidos. El primero de éstos es la familia doméstica - un conjunto de personas que en un momento dado están compartiendo una vivienda o grupo de viviendas; en nuestro caso, la toldería-, pero también grupos ampliados —incluyendo, por ejemplo, vinculaciones con otras tolderías, parcialidades o aún la sociedad criolla-. "No es sólo que el parentesco organice la comunidad — dice al respecto Marshall Sahlins_-, sino que las comunidades organizan el parentesco, de modo tal que un término espacial coexistente afecta la medida de la distancia de parentesco". Simultáneamente, el trazado de vínculos parentales contribuye o hace posible la distinción de un "otro" diferente y externo al "nosotros" definido por estos lazos, "en tanto límite que a la vez 
El espacio mesopolítico encontraría entonces un límite superior, aquel que demarcaba su relación con las autoridades provinciales. Los caciques tendrían un ámbito de maniobra sancionado y respaldado por el gobierno, dado por el cumplimiento de las exigencias. El gobierno "dejó hacer", e incluso toleró alguna impugnación o crítica, siempre que no se lo pusiera totalmente en tela de juicio. Del otro lado, habría un borde inferior, el que se establecía entre los caciques y sus agrupaciones de base, que remitiría a la reproducción social y biológica de las mismas. Los primeros tendrían que garantizar el acceso y control de recursos, pudiendo así morigerar el peso de la dominación criolla. De este modo, su autoridad dependía, en buena medida, del cumplimiento de las obligaciones marcadas por las reglas del parentesco, del grado de aceptación por parte de los que fueron sus seguidores, y de la capacidad de disuadir cuestionamientos internos acerca de su posición. Como puede verse, el espacio de actuación que queda delimitado es por demás difuso, complejo y cruzado por contradicciones; una verdadera encrucijada, pero lo suficientemente flexible como para originar una miríada de aspectos a ser estudiados.

Aquí nos ocuparemos de esto. Nuestro propósito es ver cómo impactó en la autoridad cacical su función en tanto eslabón terminal de la cadena de transmisión de órdenes hacia las parcialidades indígenas. Propondremos que se trató de una instancia compleja y cargada de tensión, dada la dificultad en la decodificación y comunicación de intenciones y determinaciones que escapaban o contradecían a las prácticas acostumbradas en las sociedades nativas. Pero más aún, porque el gobernador y sus hombres pretendían de ellos algo que no podían obtener y por tanto, tampoco garantizar: la obediencia incondicional de sus seguidores. Así, estos "interlocutores incómodos" resistieron, conferenciaron, realizaron en vano promesas, trataron de persuadir a los suyos una y otra vez y, cuando no

refuerza la identidad de sus integrantes — los 'parientes' - y excluye a los que no lo son”. De cara al exterior, garantiza o afirma la existencia de un "nosotros" comunitario, mientras que de cara al interior, el parentesco brinda un esquema a través del cual se expresan todas las relaciones básicas que dan existencia a esas sociedades. Lo que resulta de ello es una extensión de los principios que sustentan al parentesco a toda la red de prácticas que compone la situación, de manera que cada práctica que integra la red halla su modo de expresión en los términos del parentesco, que todas esas prácticas hablan el "idioma del parentesco". Las citas de Racdlife Brown, Alfred: Estructura y Función en la Sociedad Primitiva, Península, Barcelona, 1972, pág. 66; Sahlins, Marshall D.: Economía en la Edad de Piedra, Akal, Madrid, 1983, pág. 215; y Campagno, Marcelo: "Pierre Clastres y el surgimiento del Estado. Veinte años después", Boletín de Antropología Americana, 33, 1998, y Surgimiento del Estado en Egipto: cambios y continuidades en lo ideológico, Instituto de Historia Antigua Oriental "Dr. Abraham Rosenvasser”, FFyL-UBA, 1998 [1997], pág. 39. 
pudieron hacerlo, incluso lloraron. Algunos episodios que narraremos y analizaremos más adelante, darán cuenta de estos conflictivos encuentros. Sin negar la posibilidad de un entendimiento, la existencia de un espacio de convivencia o de "costumbres en común", nuestra interpretación apunta a establecer los mecanismos por los cuales se materializó la dominación de las parcialidades nativas a partir de su incorporación subordinada al territorio provincial, porque las pautas de organización nativas fueron redireccionadas por las autoridades provinciales para garantizar la "sujeción al orden" de determinados grupos. Como veremos a continuación, la política rosista tuvo un claro interés de dominación y alteración de las prácticas normativas nativas.

\section{Caciques mayores ante la encrucijada: Catriel y Cachul en el espacio mesopolítico}

La cuestión del liderazgo indígena en la región pampeana generó opiniones discordantes entre los historiadores y antropólogos que se abocaron a su estudio. La discusión parte del análisis de las transformaciones socioeconómicas aborígenes que tuvieron lugar a partir de las relaciones interétnicas y se proyecta en el tipo de organización política que las habría acompañado. ${ }^{10}$ Aquí nos adherimos a los planteamientos de Martha Bechis, ya que creemos que son los que mejor explican las características de los episodios observados en la documentación.

De acuerdo con su propuesta, la configuración sociopolítica de estas sociedades puede sintetizarse en torno a cuatro elementos. En primer lugar,

10 Mientras que Alberto Rex González y Raúl Mandrini presentan un modelo de grandes cacicatos o jefaturas, donde los líderes indígenas comenzarían a concentrar poder y a colocarse en una jerarquía diferencial producto de un proceso endógeno de diferenciación social, Martha Bechis prefiere hablar de cacicatos dotados de autoridad -no de poder, como veremos-, donde el liderazgo debía ser cuidadosamente construido y sostenido en virtud de las cualidades de sus aspirantes. Véase González, Alberto Rex: "Las exequias de Painé Güor. El sutee entre los araucanos de la llanura", Relaciones de la Sociedad Argentina de Antropología, XIII-3, Buenos Aires, 1979, págs. 137-161; Mandrini, Raúl J.: "Pedir con vuelta ¿reciprocidad diferida o mecanismo de poder?", Antropológicas, I, México, enero de 1992; y "El viaje de la Fragata San Antonio, en 1745-1746. Reflexiones sobre los procesos políticos, operados entre los indígenas pampeano-patagónicos", Revista Española de Antropología Americana, 30, Madrid, 2000, págs. 235-263; Bechis, Martha A.: "Los lideratos políticos en el área araucano-pampeana en el siglo XIX: ¿autoridad o poder?”, ponencia presentada en el I Congreso Internacional de Etnohistoria, Buenos Aires, 17 al 21 de julio de 1989, y editada en María de Hoyos (coord.): Etnohistoria, publicación especial de NAyA en CD, Buenos Aires, 1999. A modo de balance, véase Morrone: "La autoridad cacical ...". 
su organización básica era de carácter segmental, es decir, "un sistema formado por repetición de unidades casi iguales cuya división o fisión origina dos o más unidades independientes con pérdida de la estructura primigenia". ${ }^{11}$ En segundo término, los caciques articulaban relaciones de autoridad con sus seguidores, no de poder. Esta distinción analítica es por demás pertinente, toda vez que la autoridad se basa en la persuasión para canalizar la conducta de otros en ausencia de amenazas o uso de sanciones negativas (abandono, suspensión del afecto o credibilidad, burla, entre otras); mientras que el poder se sustenta en la imposición ejercida por el cacique precisamente bajo amenaza de sanciones. La autoridad ejercida por los caciques que aquí nos interesan se basaba, por tanto, en el consenso y la aceptación de sus seguidores. Se era líder porque se construía dicha posición entre los miembros del grupo. Así, los caciques tampoco poseían capacidad de imponer su voluntad ni de extraer tributos. Esta circunstancia impedía el desarrollo endógeno de un proceso de estratificación que los colocara por encima de sus seguidores. Sus actividades eran, en todo caso, más organizativas y ejecutivas que decisorias. Ese hecho se vinculaba con el tercer rasgo: el cacique era un nodo informático. La información del mundo indígena y de su exterior se concentraba en su figura para ser repartida y procesada en las juntas internas que operaban, a su vez, como informadoras. Por último, mecanismos de fusión y fisión podían regular la composición de las unidades políticas. Un cacique de menor jerarquía podía restar su apoyo o un confederado separarse -hecho que ocurría, con frecuencia, terminada una incursión a la frontera, a otros grupos o una guerra librada por cualquier razón. El contacto con la sociedad estatal criolla alentó la estructura segmental, pudiendo redundar en la fusión de parcialidades (bajo la autoridad de aquellos caciques pasibles de ser sostenidos) en el caso de los "indios amigos", o en la fisión entre los grupos que generaban problemas a las autoridades provinciales (siempre que esto no implicara la fragmentación extrema del tablero político).

Fue así que, en primer término, las autoridades criollas crearon la categoría de "caciques mayores", debajo de quienes se posicionaban los llamados "caciquillos" y "capitanejos" con sus respectivos grupos, para destacar en las agrupaciones "amigas" a aquellos interlocutores primordiales con

11 Bechis diferencia el tipo "segmental" del "segmentario", que designa "tipos de sistemas políticos basados en sistemas de parentesco unilineales cuyos linajes están en continuo proceso de oposición complementaria sin que se pierda la identidad corporativa y la estructural de ninguna de las líneas mayores o incluyentes". Bechis, "Los lideratos...", pág. 10. 
quienes entenderse y negociar, y a quienes debían procurárseles los cuidados y atenciones necesarias. ${ }^{12} \mathrm{Si}$ el objetivo del poder provincial con respecto a los indígenas consistió en "subordinarlos", "someterlos" y "sujetarlos al orden", los flamantes caciques mayores serían los agentes fundamentales. Cuando en 1835 Francisco Serantes tomó posesión de su cargo de comandante del fuerte de Azul, el edecán del gobernador, Manuel Corbalán, le informaba

que si alguna vez ocurre a ese punto el Cacique Mayor Catrie ya sea a pasar alguna larga temporada, o ya de visita, le obsequie U y atienda y facilite lo necesario según corresponde a su clase, y esto mismo encarga SE respecto del Cacique Mayor Cachul, pues que estos dos caciques son los principales y a quienes considera tener por como tales... ${ }^{13}$

12 La expansión territorial del imperio colonial hispánico en América se dio sobre sociedades organizadas según diversas configuraciones sociopolíticas. Cada situación planteó diferentes desafíos a la hora de administrar y controlar los territorios anexados. Esa diversidad podría sistematizarse de dos maneras: la refuncionalización de los liderazgos preexistentes o la inducción de liderazgos nuevos sostenidos por el estado (colonial primero, provincial después), creados casi artificialmente allí donde la dispersión sociopolítica anulaba la posibilidad de concentración interna del poder. El escenario planteado en la frontera bonaerense habría respondido a la segunda opción, por lo cual el tipo de liderazgo encarnado en los caciques conformaría un ejemplo de jefatura inducida por el interés estatal de subordinar dichas parcialidades. Por "jefatura inducida" entendemos aquellos liderazgos no prístinos, sino generados por el contacto con una entidad estatal próxima. Afirma Morton Fried: "Because the basic institutions of stateship are lacking in the invaded societies, there is no means by which the intruder can obtain the compulsive holds it requires. (...) One solution, much favored in the past, is the extirpation of the entire population. If pressure to occupy the area is not so great, other means are employed, and first among these is the imposition of external organization, a chain of command. Where no chief exists, chiefs are found, usually created by fiat." Fried, Morton H.: The Evolution of Political Society. An Essay in Political Anthropology, Harper and Row, New York, 1967, pág. 241. Véase también Nacuzzi, Lidia R.: Identidades Impuestas. Tehuelches, aucas y pampas en el norte de la Patagonia, Sociedad Argentina de Antropología, Buenos Aires, 1998, especialmente págs. 186-187 y 245-247. De otro lado, la elección de un cacique mayor por parte de su grupo se realizaba en virtud de la reunión de una serie de cualidades funcionales a los intereses de las autoridades criollas. La más importante de ellas era la cantidad de seguidores que pudiera movilizar el líder en cuestión. Aquí intervenían variables como las alianzas parentales que éste pudo y pudiera concretar, así como su control y conocimiento de la información proveniente del mundo indígena -en particular aquella que procedía de los espacios sin ocupación criolla-. Casi los mismos rasgos que reforzaban su posición ante los aborígenes que lo seguían eran estimados por las autoridades provinciales; aunque también -y se trataba de una característica relevante- su disposición a negociar con aquellas y su buena voluntad para sujetarse a sus designios. A partir de la incorporación a la provincia, se sumarían a estas condiciones su vínculo con el cacique anterior y su conocimiento del español. Al analizar el mismo problema entre los guaraníes de los siglos XVIIXVIII, Guillermo Wilde rescata un informe jesuita de 1678, en el que se acusa a los líderes impuestos "desde arriba" utilizando el revelador mote de "caciques de papel", toda vez que su única legitimidad vendría dada por la documentación colonial. Wilde, Guillermo: "Prestigio indígena y nobleza peninsular: la invención de linajes guaraníes en las misiones del Paraguay", Jahrbuch für Geschichte Lateinamerikas, 43, Colonia, 2006, págs. 119-145.

13 Archivo General de la Nación, Buenos Aires (AGN), X, 43-1-3. Manuel Corbalán a Francisco Serantes, 22 de octubre de 1835. 
$\mathrm{Y}$ es que, en efecto, lo eran y Rosas tenía la habilidad de hacérselos saber. Por endeble que pudiera haber sido su posición al momento de negociar con los criollos o si no hubieran contado con esta oportuna alianza, el gobernador siempre trataba de que se sintieran figuras fundamentales $o$, por lo menos, no percibieran su costado débil en la relación. A cambio, claro está, pretendía de ellos una serie de actitudes y conductas.

En primer lugar, se esperaba que los caciques mayores garantizaran la traducción de los designios de Rosas a la sociedad nativa. En este sentido, el intento de redireccionar su autoridad para asegurar la obediencia de sus seguidores era una constante en las atenciones del gobernador y constituía la otra cara del proceso de subordinación al orden provincial. La falta de sumisión y cumplimiento de sus disposiciones por parte de aquellos — que, como vimos, era constitutiva del tipo de liderazgo-, así como los procesos de fisión operados entre las parcialidades amigas, se contaban entre los mayores motivos de inquietud de Rosas y sus hombres. Paradójicamente, el proceso de sujeción de estas agrupaciones al orden provincial a través de sus caciques podría terminar socavando su autoridad aunque, en apariencia, la misma se viera reforzada externamente.

Catriel y Cachul también cumplían funciones diferenciadas que Rosas reconocía partiendo de sus habilidades específicas. Si el primero era hábil en asuntos concernientes a la guerra, el segundo era un hombre de política, capacidad que había que explotar. ${ }^{14}$ En palabras del gobernador,

así es que yo jamás lo he asustado en dicha pelea, por el contrario siempre he cuidado de un modo indirecto que no marche a ella, porque se que no había de hacer sino barros. Mas ese mismo hombre flojo en la pelea es muy valiente en los consejos de la política sabiendo conducir; es entonces muy útil y de mucho acierto en sus discursos. Y de aquí mismo se deriva la razón para creer que si se le desagrada y él se propone enredar, con su astucia en el manejo de la política puede haber un mal inmenso. ${ }^{15}$

Por último, se pretendía que funcionasen como agentes capaces de nuclear grupos que se querían controlar, que permitieran identificar a los indígenas incorporados en virtud de su pertenencia a las parcialidades que

14 Ratto, Silvia M.: "Soldados, milicianos e indios de 'lanza y bola'. La defensa de la frontera bonaerense a mediados de la década de 1830", en Anuario del IEHS, 18, Tandil, 2003, especialmente págs. $147-149$. $\mathrm{X}, 25-2-5$.

15 Documento trunco, por lo que no se conoce la fecha ni a quién iba destinado. AGN, 
respondían a uno de ellos. Para el arreglo y control de los "indios amigos", Bernardo Echevarría elevó a Rosas un proyecto en la primera de cuyas cláusulas sugería

dar a cada indio una papeleta que dijese (...) 'vivan los federales y mueran los unitarios' y que expresara quién es el cacique al que pertenecía (...). La especificación del cacique y oficial a que pertenecen es para ocurrir yo a ellos cuando sea necesario sin que los indios puedan sorprenderme diciéndome que pertenecen a tal cacique u oficial no siendo cierto. ${ }^{16}$

Hasta aquí, la funcionalidad que tuvieron Catriel y Cachul para las autoridades criollas en cuestión. Veamos ahora cuáles fueron los efectos de dichas condiciones al interior de las propias agrupaciones indígenas involucradas en este proceso.

Más arriba dijimos que el cacique cumplía una importante función como nodo informático y que la nueva jerarquización digitada por las autoridades creaba el cargo de "cacique mayor", uno de cuyos principales objetivos era habilitar únicos interlocutores dentro de las parcialidades amigas. El nuevo lugar que éstas les otorgaban potenciaba su rol de concentradordistribuidor de la información. Tener la posibilidad de ser el punto en que se reunían todos los datos provenientes de la sociedad criolla, así como las intenciones y disposiciones de Rosas, era de fundamental importancia en el nuevo contexto. Esto se jugaba en las constantes visitas al gobernador, en la recepción de cartas destinadas a ellos, en las permanentes entrevistas que tenían con los comandantes de los fuertes, con chasques de grupos más alejados a los que hospedaban por periodos relativamente prolongados en sus toldos y en la posibilidad de contar con lenguaraces especiales. Nótese, además, que dicho papel también existía entre los hombres de Rosas, en la medida en que las autoridades fronterizas locales reunían información proveniente de los grupos indígenas y la transmitían al gobernador.

También señalamos las dificultades de los caciques a la hora de traducir las obligaciones emanadas del gobierno provincial. La contracara de esta situación era la necesidad de contar con el beneplácito de Catriel y Cachul cada vez que los criollos querían introducir alguna innovación en las costumbres aborígenes. El ejemplo más significativo remite al uso de la fuerza por parte de Rosas y sus hombres.

16 Ibidem, 25-1-4a. Bernardo Echevarría a Rosas, 17 de enero de 1835. 
Los jefes indígenas debían, a su vez, garantizar la prestación del servicio de guerra de sus seguidores al gobierno provincial y concurrir en conjunto a las festividades bonaerenses más importantes, en las que se les asignaba un sitio especial. Fueron también instancias claves para la inclusión entre sus toldos de grupos hostiles que decidieran deponer su actitud y pactar la paz con la provincia.

Según Martha Bechis, buena parte de la riqueza y autoridad del líder provenía del excedente acumulado por la sociedad criolla, que ingresaba a las parcialidades por vía de las raciones en nuestro caso, y eran objeto de distribución. A nuestros caciques mayores correspondía la importante tarea de distribuir los bienes y animales mandados por su "hermano y amigo Juan Manuel". La autora señala que por provenir de fuentes externas, la recepción de las raciones no generaba estratificación social interna, pues no era producto de un proceso de explotación por parte del jefe. ${ }^{17}$ Estamos de acuerdo con ella en este sentido, y señalamos también que la distribución de las raciones, en la medida en que reforzaba los gestos de generosidad de aquel, fortalecía su posición en cuanto tal.

Por último, la situación quizás más importante, derivada de la relación que indígenas y autoridades porteñas habían establecido a fines de la década del veinte, se presentaba al momento de la muerte de un cacique - mayor o no- y la elección de su sucesor. Si se trataba de la defunción de un "cacique menor", hasta entonces un problema interno y responsabilidad colectiva, ahora daba lugar a la intervención de los caciques mayores y, por su intermedio, del gobernador. La primera oportunidad en que ello aconteció fue en 1834, a la muerte del cacique Anteguan en Tandil. Sin embargo, fue más complejo lo sucedido a la muerte de Juan Manuel Cachul en febrero de 1839. La necesidad de reemplazarlo requirió una cuidadosa selección del sustituto. Este hecho dio lugar, nuevamente, a la intromisión de Rosas, pero también del comandante de Tapalqué, quien solicitó "instrucciones sobre el modo como ha de manejarse la sucesión o con quién se debe entender", adjuntando "una relación de los indios más caracterizados que hay en

17 Bechis, "Los lideratos...", pág. 17. Véase también Ratto, Silvia M.: "La estructura de poder en las tribus amigas de la provincia de Buenos Aires (1830-1850)", Quinto Sol, 1, Santa Rosa, 1997, págs. 75-102. La riqueza originada en la sociedad criolla, que llega como raciones a las sociedades nativas, "is in the nature of a windfall", debe ser distribuida y no produce necesariamente niveles de estratificación social de los que puedan derivarse atributos de poder. Oberg, Kalervo: "Types of social structures among the lowland tribes of South and Central America”, American Anthropologist, 57-3, junio de 1955 , pág. 477. 
esta tribu del finado cacique poniendo al pié de cada uno de ellos su clasificación con arreglo al conocimiento que de ellos tengo". ${ }^{18}$ En esta situación, uno de los aspectos que más nos ha llamado la atención fue la existencia de "caciques interinos" que desempeñarían el cargo "hasta que SE resolviese lo que fuera de su mayor agrado". ${ }^{19}$

Para terminar, baste aclarar que Catriel y Cachul no respondían siempre de la misma manera. Su nivel de aceptación de las intenciones y directivas del gobernador variaba en cada uno y en función del contexto o la naturaleza e implicaciones de la disposición de Rosas. De los dos, el primero pareció ser quien más se ajustaba a sus decisiones y propósitos. En los documentos, su figura se perfila con ciertos aires de sumisión en todo cuanto estuviera a su alcance; podía ser una obediencia racional — producto de un cálculo que priorizara el "mal menor" - y en algún momento pudo hasta tratarse de una opción genuinamente afectiva. Cachul, en cambio, resulta un personaje atractivo al análisis por la dificultad que significaba su trato para el gobernador y sus hombres. En ocasiones las razones de su insubordinación se confunden y no está claro si era él quien no acordaba con los mandatos de Rosas, si sus seguidores podían llegar a restarle apoyo o abandonarlo si aceptaba todas sus pretensiones; a fin de cuentas, las quejas de las autoridades fronterizas se repetían.

Veamos ahora dos situaciones que revelan cuán comprometida, contradictoria y compleja podía ser la posición en que habían sido situados los caciques dentro del esquema de dominación planteado por el rosismo.

18 AGN, X, 25-6-5. Bernardo Echevarría a Juan Manuel de Rosas, 20 de febrero de 1839. Según Silvia Ratto, una de las condiciones más importantes a considerar era el trato que el futuro jefe tuviera con los criollos. Ver Ratto, Silvia M.: "Cuando las 'fronteras' se diluyen. Las formas de interrelación blanco-indias en el sur bonaerense", en Mandrini y Paz: Las Fronteras Hispanocriollas..., págs. 199-232.

19 Por informes de Echevarría pudimos saber que se trataba de Juan Manuel Cachul (hijo) y Guesache. De los mismos, el comandante dijo que "Juan Manuel Cachul es cristiano, muy apegado a nuestras costumbres, muy dócil y hace algún tiempo que manda indios, es casado al modo de los indios, quiere mucho a la madre y a las hermanas, tiene un porte de santo y franco con el que se hace querer de los demás indios y respetar y amás tiene opinión entre ellos, teniendo también la circunstancia de hablar nuestro idioma castellano como cualquier paisano de campo. Guesache capitanejo, primo del cacique Cachul, y en vida de este ha sido de su entera confianza es muy amigo de los cristianos y creo que es de mejor carácter entre todos los indios que conozco y he conocido, y según opinión de los mismos indios tiene capacidad suficiente para los parlamentos, sin embargo es en sus costumbres puramente indio pero de mucho orden y nada molesto como lo son en lo general (...) Hoy están desempeñando el cacicato hasta que VE resolviere lo que sea de su superior agrado, Juan Manuel Cachul y Guesache, el primero como hijo y el segundo como que siempre ha representado la persona del Cacique Cachul cuando venían comisiones". AGN, X, 25-6-5. Bernardo Echevarría a Rosas, 20 de febrero de 1839. 


\section{Dejaban surcar su rostro de lágrimas estrechando entre sus ásperas manos sus melenudas cabezas...}

Entre estos grupos "amigos" estaba arraigada la convicción de la inexistencia del fallecimiento natural. Pensaban que éste podía originarse en daños físicos o invisibles provocados por terceros. En el último caso, la responsabilidad del deceso se atribuía a alguien que se creía poseído por un espíritu maligno al que los indígenas daban el nombre de walichu (gualicho), y que otorgaba a quien lo hospedaba la capacidad de hacer el mal a otro. Por consiguiente, la "hechicería" se vinculaba con la muerte y sus practicantes se asemejaban a la figura criolla del asesino. El asesinato, considerado por éstos como un crimen o delito, era para los nativos un daño muy grave que requería venganza. Esta sería sangrienta y dolorosa, podía involucrar a muchos acusados — sumando en ocasiones varias decenasy generar situaciones de desorden y tensión..$^{20}$ Por esta razón, las autoridades porteñas y locales la consideraron una expresión de la barbarie en que vivían los indígenas, que únicamente debía eliminarse.

Como es de suponer, Rosas y sus hombres procuraron tomar cartas en el asunto, lo cual hicieron de distintas maneras según la gravedad del contexto y las circunstancias que se pusieron en juego en cada caso. ${ }^{21} \mathrm{Su}$ intervención recorrió un espectro que incluyó desde decisiones orientadas por criterios declaradamente humanitarios o cristianos, hasta la criminalización de una práctica nativa restitutiva de lo que consideraban un mal cometido contra alguien. Entre las sugerencias, las conversaciones, las exhortaciones y la prisión transcurrieron pocos años.

20 Para una descripción del procedimiento nativo de venganza como compensación del homicidio, véase Mc Cann, William: Viaje a Caballo por las Provincias Argentinas, Hispamérica, Buenos Aires, 1985 [1969]; y Guevara Silva, Tomás: Historia de la Civilización de Araucanía, Santiago de Chile, 1898, tomo III.

21 Una aclaración. La intromisión directa de las autoridades criollas en este tipo de cuestiones no fue igual en todo el espacio, como así tampoco se trató de una constante que recorriera el periodo rosista. Lo que destacamos aquí es la actuación de las autoridades localizada en tiempo y lugar. Los episodios encontrados remiten siempre a Tapalqué y Azul, sin registrar una sola referencia a la venganza o intentos de reprimirla entre los grupos asentados en Tandil. Esta preocupación se acentúa en las zonas señaladas desde 1835, hallando las últimas menciones documentales hacia 1838 y 1839, cuando murieron los caciques Reylef y Juan Manuel Cachul, respectivamente. A medida que se incrementaron los niveles de tensión en la frontera se fue definiendo el proceder de aquellas. En medio de un clima de marcada tensión fronteriza por conflictos entre distintos grupos indígenas, una epidemia de viruelas cobraba enormes cantidades de víctimas entre los indios. La enfermedad y la muerte de los infectados eran atribuidas a alguien captado por gualicho, lo cual daba lugar a extendidas venganzas. 
Uno de los relatos que Prudencio Arnold dejó sobre su paso por la frontera narra el encuentro entre Echevarría y los caciques mayores, en que el primero intentaba hacerles entender la necesidad de abandonar aquella costumbre. ${ }^{22} \mathrm{El}$ comandante puso en juego todos los argumentos posibles, desde la idea de que sólo Rosas era quien podía castigar hasta el tipo de vínculo que los unía al gobernador y a sus antepasados. Y aunque el mensaje parece haber sido comprendido por sus destinatarios, la narración da cuenta de cómo la conversación se desarrollaba en registros distintos, además de mostrar la actuación de las autoridades provinciales para eliminar esa costumbre indígena. Mientras Echevarría sugería la necesidad de un castigo que Rosas podía ejecutar, Catriel y Cachul pensaban en una venganza que de algún modo reparaba el daño ocasionado y alejaba para siempre a los portadores del espíritu maligno. Según Arnold,

no transcurrió mucho tiempo sin que se nos ofrecieran nuevos casos de gualichu; es decir, sin que hubieran en perspectiva nuevos más para ser sacrificados por esa preocupación de los indígenas. Dos jóvenes indias llegaron ocultamente hasta la comandancia, pidiendo protección. Dársela era comprometer la vida de todos los cristianos que allí había, si los indios lo sabían. Difícilmente podía también ocultarse cuando se estaba en medio de ellos y por entre ellos había que salir a largas distancias". ${ }^{23}$

Perceptivo, Arnold entendía que ayudar a escapar a las mujeres los colocaba ante un riesgo de múltiples aristas: convertirse en cómplices del daño generado, pasar por encima de la autoridad que el mismo Rosas otorgaba a los caciques mayores frente a sus agrupaciones y desautorizar a la comunidad implicada en la ejecución del resarcimiento correspondiente, al tiempo que los parientes del damnificado quedaban sin satisfacción de su "revancha". Para peor, era muy fácil que los "indios amigos" se enteraran de las actuaciones de Echevarría, quien decidió enviar a las mujeres a la guardia de Monte escondidas en las carretas del comerciante don Isidro Jurado. Se procedió, entonces, con los más absolutos silencios y decoros posibles, pero era imperioso hacer algo más.

22 Prudencio Arnold fue un soldado que participó de varias contiendas bélicas en la región. De sus andanzas por la frontera, sabemos que estuvo en Tapalqué durante algún tiempo, aunque no podemos fechar su estadía con exactitud, ya que el capítulo correspondiente no la explicita. Empero, por el cotejo de datos que aparecen en las narraciones de Arnold con fuentes de archivo creemos que su estancia en Tapalqué puede datarse en 1836-1837. Arnold, Prudencio: Un Soldado Argentino, Eudeba, Buenos Aires, 1970, especialmente cap. VIII.

23 Ver todo el relato en Ibidem, pág. 100. 
Cuando se supo que estaban libres, era necesario hacerlo saber a Catriel, porque la vida de todos corría riesgo, pues silenciar el hecho y fiarlo al secreto era doble peligroso, mucho más cuando ya no era un secreto desde que todos los peones de las carretas lo sabían y con el tiempo lo descubrirían comprometiendo en ese caso, hasta las relaciones de paz y amistad que el gobierno mantenía con aquellos indios. A pesar de estas consideraciones, se vacilaba mucho resolverse a dar cuenta del hecho a Catriel. ¿Qué hacer entonces? Era forzoso tomar alguna determinación decisiva. Mi amigo Echevarría en tales aprietos concibió y realizó la idea de llamar a conferencia secreta a los caciques mayores Catriel y Cachul, en la comandancia, con la esperanza de sacar alguna ventaja del respeto y mucho amor que estos jefes indígenas tenían por el general Rosas.

Recordemos que era menester obtener el beneplácito de Catriel y Cachul cada vez que las autoridades criollas introducían alguna innovación en las costumbres nativas. Echevarría optó entonces por llamar a conferencia a los caciques. Echando mano de un proceder al que ya había recurrido en otras oportunidades, el comandante aprovechó para informarlos de las medidas adoptadas e insistir en sus peticiones de que abandonasen la costumbre de "matar por simples órdenes de ellos". Como vimos, los caciques debían traducir al interior de sus parcialidades las determinaciones de las autoridades provinciales a la vez que erigirse como modelo de comportamiento para sus seguidores. De esta manera, Echevarría buscaba también que cada quien ocupase su lugar en este esquema vincular apelando, no casualmente, al "respeto y mucho amor que estos jefes indígenas tenían por el general Rosas" señalado más arriba.

Cuando estuvieron reunidos, Echevarría dijo a Catriel: 'Los he llamado para que hablemos los tres solos, porque están haciendo matar indios y chinas por el gualichu'. Catriel contestó: 'Es cierto: nuestros padres nos han enseñado que nosotros tenemos que hacerlo'.

-Ustedes ven que cuando un cristiano mata a otro, le roba o le hace otra cosa —replicó Echevarría - se manda preso para que el gobierno lo castigue; pero nosotros no podemos matarlos de ninguna manera.

-Sí, es cierto.

-Pues, ustedes deben hacer lo mismo.

-No podemos modificar lo que nuestros padres nos enseñaron.

La respuesta de Catriel desarticuló el discurso del comandante. El cacique dio una razón que explicaba las causas de la recurrencia en la costumbre de "matar indios y chinas por el gualichu". Cuando Catriel afirmó "nuestros padres nos han enseñado que nosotros debemos hacerlo", le dijo a Echevarría que esa práctica era antigua y tenía una lógica dentro de la comu- 
nidad; era una legítima tradición ancestral, profundamente imbricada en el legado de sus "padres", autoridades irrecusables en una sociedad organizada en función del parentesco. Sin embargo, esta autoridad encontró un modo de contraatacar discursivamente la ofensiva, aleccionando a los caciques sobre las situaciones en que el gobernador podría intervenir. "Cuando un cristiano mata a otro" se lo mandaba preso para que el gobierno lo castigara, pero también cuando "le roba o le hace otra cosa". Echevarría definió los ámbitos de acción privativos de Rosas — robos o asesinatos-, pero la imprecisión de la última frase dejaba abierta, entretanto, la posibilidad de añadir potenciales ocasiones. No obstante, era claro que nadie podía matar "de ninguna manera", y que ellos debían "hacer lo mismo".

Más aún, los caciques parecían encontrarse en la difícil disyuntiva de abandonar una costumbre que — repetimos — se vinculaba inextricablemente a la creencia de que nadie muere naturalmente y a la idea del daño cometido. El dilema giraba en torno a la imposibilidad de convivir con quien había hecho el mal y que, por tanto, podía volver a hacerlo. La sanción ejecutada por la comunidad en casos de gualicho tenía por finalidad reparar el daño, restablecer la concordia y erradicarlo. Echevarría pedía que se permitiese la intervención del gobierno en estas cuestiones y que ellos enviasen a quienes creyeran culpables del mal para que las autoridades provinciales los castigasen.

Nos preguntamos, entonces, qué podían hacer los caciques mayores y cómo comprender, procesar y traducir a sus seguidores estas delicadas cuestiones obteniendo a cambio —como esperaban los hombres de Rosas-, nada menos que su aceptación y obediencia. Pero la cuestión no terminó allí. Dice Arnold que Echevarría agregó:

- Juan Manuel también es padre de ustedes; y como nosotros mandamos a los que faltan, también ustedes deben mandarlos.

Catriel tuvo a bien guardar silencio.

-Ustedes son hijos de Juan Manuel —repitió Echevarría-, y él los quiere mucho. A mí me han enviado aquí para que los cuide porque son sus hijos. Yo también tengo buen corazón para con los indios...24

Quisiéramos reparar en la apelación directa que hace Echevarría al contenido emotivo y personal implicado en las relaciones que los "indios amigos" tenían con Rosas. "Juan Manuel también es padre", y el comandante estaba allí porque ellos "son sus hijos" habiéndole enviado "para que

24 Cursivas nuestras. 
los cuide”. Recurrir a la figura parental del gobernador permitía desbalancear la estructura jerárquica de autoridades y redefinía a los responsables de la reparación del daño: si vengar a quienes hacían un maleficio, tal como los pampas lo practicaban, era válido porque así lo habían enseñado sus padres, pues bien, Juan Manuel también era su padre, y a él había que "mandar a quienes faltan", para que los castigase. La habilidad de Echevarría residía en construir un discurso cifrado en el lenguaje del parentesco. Aludiendo a vínculos familiares, abría el juego a que los caciques resituaran los hechos en otro contexto organizacional, discursivo y práctico en su propia sociedad. Es el pariente, ante todo el padre, quien castiga: Juan Manuel es padre y, entonces, castiga. Ellos son hijos, obedecen a Juan Manuel. Echevarría está ahí para cuidarlos porque los indios amigos son hijos queridos de Rosas.

La documentación del periodo es consistente a la hora de delimitar los márgenes de pertenencia. No casualmente, el elemento que posicionaba tanto a los unitarios como a las parcialidades "enemigas" en el lugar del peligro eran los mismos lazos de parentesco que ataban a los "amigos" indígenas y "cristianos" federales. En el discurso del rosismo, éstos últimos eran hijos de un gran padre - Rosas - y estaban ligados entre sí por relaciones fraternales. Quien rechazara integrarse a esos lazos se posicionaba en contra de ellos y del espacio cohabitado por el grupo definido como el conjunto de dos sociedades amigas, que pasaban a ser una misma. En tanto "no parientes" eran extraños y acechaban perniciosamente la felicidad de la provincia. En efecto, el parentesco proporcionaba un eficaz criterio de inclusión-exclusión: quien no estaba dentro de la comunidad de parientes era enemigo y salvaje, inmundo y asqueroso.

Arnold capta magistralmente el impacto que tuvieron las palabras de Echevarría en los caciques y comenta: "Catriel tuvo a bien guardar silencio". El comandante continuó:

'Por eso le mandé [a Rosas] dos chinas que vinieron aquí diciéndome que las iban a matar, para que Juan Manuel las castigue, si ustedes le dicen que han faltado'. Guardaron nuevamente silencio, observándose que gruesas lágrimas rodaban por sus mejillas. Todos los esfuerzos de Echevarría para obtener más ventajas de estos dos caciques fueron inútiles. Cuando más los apuraba con razonamientos a fin de que no continuasen la bárbara costumbre de matar por simples órdenes de ellos, se ponían de pie, se agarraban la cabeza y lloraban sin pronunciar una palabra. ${ }^{25}$

25 Cursivas nuestras. 
Echevarría tocó el punto neurálgico del problema: comunicó que las mujeres habían sido enviadas para que fuera Juan Manuel quien las castigase si ellos confirmaban "que han faltado". La autoridad de Catriel y Cachul ante sus indios se había desdibujado, había sido tomada sin más por el comandante del fuerte, y nunca podrían explicar lo ocurrido a quienes buscasen a las responsables, los cuales posiblemente no terminaran de comprender por qué Echevarría administró el asunto a su parecer. Ante un comandante que intimaba a abandonar una práctica dotada de sentido entre los pampas, y que resolvía e intervenía en el conflicto sin más reparos que los que concernían al propio sostenimiento de la "paz" alcanzada con estos grupos, la respuesta de Catriel y Cachul no podía ser otra: los caciques permanecieron en silencio y rompieron en llanto. "Así terminó esta conferencia - asegura Arnold-, sin que por parte de ellos quedase aprobada o desaprobada la medida tomada por Echevarría y sin prometer reforma alguna".

Era claro que los caciques no podían garantizar el abandono de la venganza y, mucho menos, la eventual respuesta de sus seguidores. No les era posible transmitir lo "intransmisible" — la expropiación de sus facultades colectivas por las autoridades criollas_-; y aunque pudieran, no tenían la capacidad de recurrir a la fuerza para obligar a quienes no comprendieran la situación planteada, o a quienes se negaran a obedecer.

De esta manera y en medio del desierto demostraron aquellos hombres salvajes el respeto sagrado e irrevocable que tenían por las leyes transmitidas por sus ascendientes; leyes inculcadas en sus corazones de tal suerte, que antes de violarlas aún invocando la veneración que tenían por el señor general Rosas, dejaban surcar su rostro de lágrimas, estrechando entre sus ásperas manos sus melenudas cabezas.

Es importante este último comentario de Arnold porque, como podía esperarse, los indígenas continuaron con las venganzas por gualicho. Echevarría insistiría muchas veces al gobernador, a fin de que le indicara el procedimiento a seguir.

\section{Lo opuesto que es a sus leyes o costumbres el valerse ellos mismos de la fuerza...}

Entre 1838 y 1840 el rosismo atravesó una crisis inédita en su gravedad. El bloqueo francés del puerto (que afectó las finanzas públicas y privadas), la conspiración de Ramón Maza, el alzamiento de los llamados 
"Libres del Sud", rumores y amenazas de motines y sublevaciones en la campaña, y la invasión de Juan Lavalle, entre otros acontecimientos que tuvieron lugar en esos tres años, llegaron a jaquear una autoridad que hasta entonces se presentaba, cuando menos, indiscutible. La imagen demonizada del unitario amenazando la vitalidad del régimen rosista y la seguridad de las poblaciones se extendió con rapidez. De la misma manera lo hizo el terror, que debía apagar cada pulso, cada aparición fugaz o real del enemigo. ${ }^{26}$

El esfuerzo por combatir tantos focos de conflicto comprometió a toda la población en el rescate del régimen, al que sostuvieron con sus bienes o su vida. El resultado fue una activa militarización de la sociedad, de la que no escaparon los grupos nativos asentados en el sur de la provincia. Su más activa participación tuvo lugar en la represión del alzamiento de los "Libres del Sud". ${ }^{27}$ El levantamiento tuvo como epicentro los pueblos de Dolores y Chascomús. Buena parte de sus líderes y principales complotados se contaban entre los más ricos propietarios rurales y los jefes militares de la campaña sur. Allí se emplazaban las mayores fortunas ganaderas y allí se suponía que también se concentraban los más incondicionales apoyos del rosismo.

Cuando circuló entre los grupos amigos la noticia de la sublevación, éstos se aprontaron a ofrecer su ayuda al gobierno. Sin embargo, Prudencio Rosas - que lideraba las fuerzas rosistas en Azul- no los contó entre sus tropas en la batalla de Chascomús, el 7 de noviembre de 1839. Rosas no recurrió a ellos sino hasta último momento, cuando tres días después los rebeldes se apoderaron del Fuerte Independencia. Posiblemente, el gobernador no haya querido movilizarlos a fin de evitar desmanes y robos en las inmediaciones; y los hechos contribuyen a explicar mejor su decisión.

El 5 de noviembre, Francisco Romero - a cargo de un campamento de la División del Sud — había escrito a Manuel Capdevila — juez de paz y comandante accidental de Azul - que "en este momento se acaba de sublevar la indiada retirando sus familias con malas intenciones hacia nosotros", por lo que solicitaba la ayuda del fuerte. ${ }^{28}$ Al parecer, los unitarios

26 Una síntesis del contexto en Salvatore, Ricardo: “Consolidación del régimen rosista (18351852)" en Goldman, Noemí L. (dir.): Revolución, República y confederación (1806-1852), t. III de Nueva Historia Argentina, Sudamericana, Buenos Aires, 2005, págs. 323-380.

27 Un relato general de la sublevación en Gelman, Jorge: "La rebelión de los estancieros contra Rosas. Algunas reflexiones en torno a los Libres del Sur de 1839", Entrepasados, 22, Buenos Aires, 2002, págs. 113-144.

28 AGN, X, 20-10-1. Francisco Romero a Manuel Capdevila, 7 de noviembre de 1839. 
habían intentado captar a los indígenas para su causa, diciéndoles que Rosas había muerto. Para ello, sabiendo el lugar que cabía a los caciques frente a sus seguidores, se valieron de chasques que comunicaron a Catriel la falsa noticia. Creemos que la opción por este jefe indígena pudo deberse a su ascendente entre la población nativa, así como a las probadas muestras de fidelidad que había manifestado hacia el gobernador. Convencer al cacique abría la posibilidad de contar con el apoyo de sus seguidores a favor de la sublevación porque, en ausencia de Rosas, ya no habría pacto con los criollos.

De inmediato, las autoridades provinciales tomaron cartas en el asunto: era menester convencer a los indios de la falsedad de los argumentos unitarios. Nicolás Granada, que comandaba la División del Sud y había salido con algunos aborígenes del campamento, mandó enseguida dos lenguaraces a persuadirlos del ardid enemigo. Pero la noticia ya se había expandido con rapidez, y fue preciso pedir a Rosas que con urgencia enviase de vuelta a los caciques Nicasio y Quiñigual, que estaban en Buenos Aires, para que dieran fe de haber visto con vida y en perfecto estado de salud al gobernador. ${ }^{29}$ Entretanto, se sugirió a Pablo Muñoz - comandante de Tandil - que obrase del mismo modo con el cacique Callfiao, a fin de evitar confusiones también allí. Por nota del 7 de noviembre se informaba al gobierno que todos se habían "sosegado". ${ }^{30}$ Pero pese a los esfuerzos realizados, persuadir a Catriel no parece haber sido tarea fácil. Enviado por el gobernador, el 13 de noviembre acudía al toldo del cacique el lenguaraz Manuel Baldevenito, para repetir que no se dejasen engañar por los "salvajes unitarios sublevados", y que "unidos a los cristianos federales" pelearan a favor de la causa rosista, ayudándolos a perseguir a los insurrectos.

Hasta aquí, el cacique había sido objeto de mensajes y contramensajes, tanto de quienes se levantaban como del régimen mismo. Pero desvanecidos los rumores y aquietados los ánimos, lo peor estaba aún por venir.

Como dijimos, el fuerte Independencia cayó el 10 de noviembre en manos de los Libres del Sud. Fue entonces cuando Rosas decidió involucrar a los nativos en la contienda. Bernardo Echevarría y el mayor Eugenio

29 Ibidem. Francisco Romero a Manuel Capdevila y Manuel Capdevila a Manuel Corbalán, ambas notas del 5 de noviembre de 1839. Juzgado de Paz de Azul.

30 Ibidem. Francisco Romero a Manuel Capdevila, 7 de noviembre de 1839. 
Bustos se pusieron en marcha rumbo a Tandil "con una fuerza de 400 indios amigos pertenecientes al campamento de Tapalqué y ciento y más cristianos habiendo dejado parte de esta indiada en el campamento". ${ }^{31}$

Si la razón de Rosas para no movilizarlos había sido el temor a los desórdenes que los indígenas pudieran cometer, los hechos dieron fe a sus presunciones. El grupo que el comandante de Tapalqué dejó en el campamento se dispersó en partidas que robaron caballos, saquearon estancias y mataron a una persona "manifestando en sus procedimientos la ninguna confianza que en ellos se puede tener". ${ }^{32}$ Desde ese momento, los caciques fueron víctimas de una nueva doble presión, pero esta vez más compleja: sus seguidores se negaban a sujetarse al orden y continuaban en sus conductas "desaprobadas", mientras que el gobierno insistía una y otra vez en la necesidad de detener los "desastres" ocasionados en la campaña. Inmediatamente, Manuel Capdevila envió un chasque a Catriel pidiendo explicaciones sobre la actitud de sus indios y solicitándole pusiera pronto remedio a la situación. La respuesta del cacique fue la esperable: había estado lejos de los suyos, por lo que había escapado de sus manos lo sucedido; sin embargo, prometía arreglar las cosas cuanto antes.

Llegados a este punto conviene retener dos cuestiones. En primer lugar, fue nuevamente Juan Catriel a quien acudieron las autoridades criollas. Nótese, a su vez, que hasta aquí no hemos hablado de Juan Manuel Cachul. La razón estriba, precisamente, en que las fuentes tampoco lo mencionan. Las negociaciones se establecieron en principio con quien fue, al parecer, el único jefe indígena capaz de escuchar a los hombres del gobernador, ser convencido y efectuar una traducción de estas peticiones hacia sus seguidores, incluso hacia el mismo Cachul. Que sus intentos no hayan resultado remite, en todo caso, a su comprometido lugar y a su imposibilidad de recurrir al uso de la violencia. He aquí nuestro segundo reparo: pese a los repetidos intentos de las autoridades, el cacique no iba a poder cumplir con su palabra; apelaría a la persuasión, pero esto no daría resultado ante el curso que tomaban los acontecimientos.

En efecto, la recuperación del fuerte Independencia sería obra de los "indios amigos". A partir de ese momento, éstos se entregaron al desmantelamiento de las casas de negocio de Tandil y tomaron todo el ganado que encontraban a su paso, sin discriminar si se trataba de animales de

31 Ibidem. Manuel Capdevila a Manuel Corbalán, 15 de noviembre de 1839.

32 Idem. 
federales o de unitarios. ${ }^{33}$ Reiterada la interpelación al cacique para que diera cuenta de tan inadecuado proceder, éste justificó el desorden alegando desconocer a quienes obraban de modo tan escandaloso. No obstante, autorizaba a Capdevila a tomar y fusilar a quien encontrara apropiándose de ganado o bienes ajenos y no tuviera autorización para transitar. ${ }^{34}$ En otros términos, el cacique habilitaba a las autoridades criollas a recurrir al uso de la violencia porque él no podía hacerlo y, por tanto, sólo podía apelar a las palabras para calmar los ánimos, procedimiento que se mostraba sobradamente improductivo en esta oportunidad. Sin embargo, que Catriel habilitara al comandante a aplicar la fuerza sobre quien incurriera en actitudes reprobadas no significaba que perdiera autoridad frente a sus seguidores. Dejar el asunto en manos de los criollos era la única alternativa, pero éstos no podían emplear tal mecanismo sin su consentimiento. Así planteadas las cosas, ¿se licuaba o se reforzaba la autoridad del cacique?

Sea como fuere, el 19 de noviembre los indígenas de Tandil y los que habían concurrido allí con Echevarría decidieron marchar a Tapalqué. El conflicto surgió porque habían robado animales, siendo preciso además "advertir a los vecinos que se pongan en seguridad pues es probable que en su tránsito cometan mil excesos" ${ }^{35}$ En efecto, el 30 de noviembre Echevarría informaba al gobernador que si la cantidad de ganado robado había sido estimada en siete mil cabezas, cálculos más precisos arrojaban la suma de dieciséis mil animales y que, por este motivo, durante la tarde anterior habían conferenciado con Catriel.

En esta carta, el comandante de Tapalqué transmite con claridad la posición del cacique que, en sus palabras, "manifiesta y los tiene los mejores deseos por el restablecimiento del orden y devolución de las haciendas". Sin embargo, la agitación que el levantamiento había generado y el estado de intranquilidad que aún se respiraba en la campaña conspiraban contra las intenciones del jefe indígena. Así fue que

33 Tras la derrota de los sublevados, Echevarría tuvo que conciliar con los nativos, lo cual por cierto no fue tarea fácil: "Entre otras de las cosas que esos malvados les habían hecho entender a los indios una de ellas era la de que del Azul para acá todos eran contrarios a SE Nuestro Ilustre Restaurador de las Leyes y por ello los indios nos decían que era mentira nuestra que esos caballos eran de los enemigos de SE y que quien sabe si no los engañábamos". Cursivas nuestras. AGN, X, 2010-1. Echevarría a Capdevila, 16 de noviembre de 1839.

34 Ibidem. Manuel Capdevila a Manuel Corbalán, 18 de noviembre de 1839.

35 Ibidem. Bernardo Echevarría a Manuel Capdevila, 19 de noviembre de 1839. 
vemos y palpamos que esto no pasa de la esfera de los buenos deseos por su parte y que en el carácter bélico de los indios, y la conmoción general que éstos han experimentado, a causa de las desconfianzas y demás perniciosas ideas que los salvajes unitarios les habían sugerido, la obediencia a este cacique, no es sino en apariencia y en todo aquello que a ellos les conviene. ${ }^{36}$

Como podía esperarse en contextos tan complejos, los hechos continuaron complicándose, esta vez con un intento de alzamiento de los grupos amigos.

El 3 de diciembre, Echevarría informaba al sargento mayor Eugenio Bustos que "los indios de este punto tratan de sorprendernos", dato no menor puesto que "la fuerza numérica de esta indiada es, en proporción de las que tenemos al presente a su inmediación, algo respetable". Para peor, por el lenguaraz de Catriel el comandante supo "que los indios le han hecho entender al cacique Catriel que en Pluma Aujero hay una fuerza cristiana para atacarlos a ellos en combinación con la del Coronel Granada, que ellos se ponen en marcha para este destino", y que Catriel había contestado que "si eso es así, es preciso concluir con los cristianos...". ${ }^{37} \mathrm{El}$ cacique era, nuevamente, objeto de las presiones de sus seguidores, manifestadas como un rumor dotado de bastante fuerza, destinado a lograr su participación en el motín.

Quien coordinaba el alzamiento era Callfiau, sucesor del cacique Anteguan y líder de los grupos nativos de Tandil. Estaba en connivencia con indios de origen chileno que habían enviado chasques a sus toldos y que pensaban atacar la provincia por el sur. Hábilmente, Callfiau había buscado primero la complicidad de Catriel con un discurso capaz de impactar sobre éste. Con Cachul había hecho algo semejante: lo sedujo con un razonamiento que decodificaba y traducía el modo en que Callfiau percibía y comprendía la incorporación al "Negocio Pacífico de Indios": quiso "decirle que al abuelo lo habían muerto los cristianos, que al padre lo habían tenido en prisiones los mismos, y que a él lo estaban amansando para hacer lo mismo". ${ }^{38}$ Frente al sargento mayor Bustos, Callfiau había dejado explicitada su posición, diciendo "con palabras terminantes [y] no en estado de embriaguez, sino muy cuerdo [que] ¿quién les ha dado licencia a los cristianos para poblar esta guardia [Tandil]? Mi padre, que fue el dueño de

36 AGN, X, 25-6-5. Bernardo Echevarría a Juan Manuel de Rosas, 30 de noviembre de 1839.

37 Ibidem. Bernardo Echevarría a Eugenio Bustos, 3 de diciembre de 1839.

38 Cursivas nuestras. El comandante emplea el término "insurrectos" porque, en efecto, Callfiau era secundado por otros jefes indígenas menores: Crejo, Corrupan, Cayupan y Guirquiley. Ibidem. Echevarría a Rosas, 4 de diciembre de 1839. 
estos campos, no se las ha dado". ${ }^{39}$ Según Echevarría, los indios buscaban intimidar a Cachul, "obligarlo a que cometa un atentado y quedar ellos siempre garantidos con la obediencia al cacique". ${ }^{40}$

Lo cierto es que fue Catriel -y no Cachul— quien recibió al día siguiente otro chasque de las autoridades criollas. Manuel Baldevenito trajo el mensaje del comandante de Tapalqué:

no haga caso de lo que le dicen los indios, que todo es por la envidia que tienen de la grande amistad que VE le profesa; que se fije en las personas que le vienen con estos chismes, y verá que ninguno es tan antiguo en la amistad con VE como lo es él y que ninguno es más de orden y amigo de los cristianos que él, su familia y sus indios, que puede ser muy bien que lo quieran engañar, para ver si lo separan de la amistad de los cristianos, cosa imposible, porque SE lo quiere mucho, y que tal vez esos mismos que hoy le aconsejan mal, es porque creen que son capaces de hacerlo separar de la amistad de SE para después hacerlo padecer o matarlo a pesadumbres, sacándole en cara los regalos que SE le ha hecho y últimamente, hacer de él lo que les diese la gana y hasta negarle la obediencia.

El comandante apelaba a los vínculos afectivos que, en su discurso, ligaban a Catriel con Rosas, para poner del otro lado, como en un juego de espejos, a quienes trataban de persuadirlo para sublevarse escondiendo, en realidad, siniestras intenciones. ¿A quién creerle? Catriel optó por dar fe a las palabras de Echevarría, mostrándose "pesaroso porque cree que sea ofensivo lo que los otros indios le han dicho de que los cristianos los quieren atacar", ${ }^{41}$

Ahora bien, veamos qué ocurrió con los animales que los indios robaron al calor de la revuelta, porque contribuye al análisis del problema que nos ocupa. Habíamos adelantado que, en especial cuando se recuperó el fuerte Independencia, los indígenas se alzaron con cuantos animales encontraron a su paso sin discriminar si sus dueños eran unitarios o federales, en cifras que rondaban las dieciséis mil cabezas. Las autoridades criollas trataron de conseguir la devolución de la hacienda, apelando nuevamente a los caciques como mediadores. Se les convocó una y otra vez para que dieran cuenta de la mala conducta de sus seguidores, de la lentitud con que éstos se presentaban a los apartes y de las múltiples escaramuzas que encontraban

39 Ibidem. Aquí Callfiau se refiere al pueblo de Tandil, específicamente a los alrededores de fuerte Independencia, cuya edificación en 1824 implicó la ruptura del Tratado de Miraflores, como vimos en la nota 3. de 1839.

40 Cursivas nuestras. Ibidem. Echevarría al sargento mayor Eugenio Bustos, 3 de diciembre

41 Ibidem. Echevarría a Rosas, 4 de diciembre de 1839. 
para no entregar el ganado. Por supuesto, la actitud de Cachul continuó siendo reticente, dando lugar a las reiteradas reclamaciones de aquellas. Catriel se mostró, nuevamente, más dispuesto a la negociación: habló con los suyos y, según los hombres de Rosas, les imploró que de todas formas cumplieran con la petición. Que no hubieran dado resultado sus súplicas o exhortaciones respondía a cuestiones que escapaban a su voluntad, ya referidas, entre ellas la imposibilidad de los líderes indígenas de recurrir a la fuerza. Sin embargo, el cacique también mostró sus posibilidades de concertación.

El 11 de diciembre, Echevarría tuvo una "conferencia fuerte" con Catriel, a fin de que hiciera "el esfuerzo para que abrevie la entrega de las haciendas". En la conversación, Catriel manifestó que lo intentaría una vez más, pero la charla concluyó de un modo que probablemente el comandante no esperaba. El cacique terminó diciéndole "que tenía un indio preso, que este era de los de Tandil y pariente de una de sus mujeres, y que quería que yo [Echevarría] me interesase con Ud. por su libertad". Y si bien el comandante salió airoso — respondiendo que nada podía hacer, que Manuel Capdevila había tomado cartas en el asunto y que probablemente las determinaciones posibles ya estuvieran en manos de Rosas-, el episodio muestra hasta qué punto el cacique conservaba una nada despreciable capacidad de negociación. El mismo Echevarría lo hizo explícito cuando imploró a su par de Azul que en su respuesta le informase sobre la situación del indígena al que Catriel reclamaba, argumentando que "hoy más que nunca conviene satisfacer al cacique en razón a que en este momento manda el cacique Catrie una porción de capitanejos con indios a los apartes de las haciendas de los cristianos".

La secuencia es clara: el comandante pidió la devolución del ganado robado y el cacique solicitó la libertad de uno de sus parientes. Echevarría logró evadir la demanda del cacique pero, al mismo tiempo, rogó a Capdevila noticias - no sería extraño que Catriel reiterara la petición- y lo fundamentó explicitando el modo en que Catriel se convertía en una irremplazable pieza de conexión entre la sociedad indígena y los deseos de las autoridades criollas. Más aún, los capitanejos destinados a efectuar las separaciones de hacienda llevaban "la orden de que si los otros indios no quieren por bien, se les quiten por la fuerza toda". Claro que no serían los indígenas quienes emplearían ese procedimiento con aquellos que se negaran a entregar los animales, pero nuevamente era Catriel quien permitía la apertura de un canal hasta entonces no ocupado por ninguna autoridad en la sociedad nativa, lo cual para Echevarría era positivo "porque ya el caci- 
que entra a tomar una parte activa". ${ }^{42}$ Creemos que el comandante no desacertaba en su juicio: que Catriel no perdiera autoridad frente a sus seguidores tampoco implicaba que ésta no experimentase cambio alguno.

Resta decir que la situación continuó sin resolverse de inmediato. Las buenas intenciones de los indígenas persuadidos por su cacique mayor apenas duraban días; y otra vez los chasques, otra vez los parlamentos, otra vez las promesas que no podían cumplirse. No obstante, a comienzos del año siguiente el orden había vuelto a la campaña y las cosas comenzaban a calmarse. "Eso sólo era obra del tiempo y la constancia", decía atinadamente el comandante de Tapalqué, razón por la cual había dejado de hablar del tema con los caciques durante unos días:

Y cuando he visto que los indios venían a pedirme yerba, azúcar y otras frioleras como tenían de costumbre, que ellos y sus familias entraban sin desconfianza dentro del zanjado, y que los indios se reunían los domingos con los cristianos en las carreras, y que ya los vi llenos de confianza, entonces ya les hablé a los caciques de este punto y del Tandil, que son Callfiau, Maicá y Pety.

Con cada uno, las formas y las razones habían sido distintas y ello obedecía a que Catriel y Cachul guardaban otra relación con el gobernador y sobre ellos recaían otras expectativas. Por primera vez aparece Cachul dialogando con Echevarría. Al igual que Catriel, se mostró disgustado por el engaño que había sufrido y "hasta avergonzado de haber creído en los embustes de los otros indios". Respecto de la entrega de la hacienda, dijo que hacían ellos cuanto podían, "que algunos oyen sus consejos, pero que hay entre ellos como entre los cristianos algunos malos, que con estos me entienda yo del modo que me parezca, significándome, de un modo indirecto lo opuesto que es a sus leyes o costumbres el valerse ellos mismos de la fuerza para estos casos". ${ }^{43}$

\section{Consideraciones finales}

En este trabajo partimos de entender el "Negocio Pacífico de Indios" como una forma especial de hacer política, en el seno de la cual Rosas pretendió subordinar la población nativa local al nuevo orden estatal. Entre

42 Archivo Histórico de la Provincia de Buenos Aires, Juzgado de Paz de Azul (1839-1842), 39-1-1. Bernardo Echevarría a Manuel Capdevila, 12 de diciembre de 1839.

43 AGN, X, 25-8-3. Echevarría a Rosas, 11 de enero de 1840. Cursivas nuestras. 
otras prácticas, recurrió para ello a la creación de interlocutores primordiales, los caciques sindicados como "mayores". Asimismo, propusimos avanzar sobre algunas líneas de análisis teórico e intentamos esbozar nuevos conceptos que nos permitan pensar esa compleja trama de relaciones establecidas entre las autoridades fronterizas y los caciques, ese eslabón terminal que ató el nudo de poder local.

Quisiéramos entonces, cerrar este artículo con algunas consideraciones en torno a lo que significó el "Negocio Pacífico de Indios" para los líderes étnicos. Una coyuntura crítica abierta entre fines de la década de 1810 y principios de la siguiente los llevó a ingresar en un tipo de relación más directa y personal con las autoridades provinciales y con el propio gobernador. A partir de ese momento, tanto la apropiación de las capacidades punitivas de los líderes parentales nativos, como el mayor control sobre los robos de ganado por parte de los poderes provinciales, hicieron manifiesta esa contradicción habitada por los caciques.

Participar de un espacio mesopolítico habría incluido, como ya dijimos, una capacidad de traducción difícil de percibir por fuera de la situación específica. Esos caciques atravesaron una dualidad contradictoria: garantizar las condiciones de reproducción de sus agrupaciones de base, al tiempo que se plantaba un intento de intervención estatal que poco en común tenía con las pautas de organización, sustentadas en el parentesco, la reciprocidad y la imposibilidad de concentración del poder. En esta coyuntura, ¿qué margen de neutralidad quedó para ellos? Ubicados entre dos polos de una relación, ¿de qué habrá dependido que los jefes étnicos hayan atendido a una u otra fuerza? ¿Eran líderes de sus parcialidades, funcionarios estatales, o una imbricación coyunturalmente situada de ambos caracteres? Creemos que esta tensión no se mantuvo inalterada en todo el perdíodo, sino que más bien debe haber obedecido a los márgenes de acción que cada contexto habría planteado. De todos modos, ubicados en cualquier segmento del par colaboración/resistencia, Catriel y Cachul distaron de ser meros intermediarios neutrales.

En el episodio de mediados de la década de 1830 narrado por Arnold, vimos a los caciques acorralados por la normativa rosista que les impedía vengar las muertes por "engualichamiento". La apelación al idioma del parentesco resignificada por el discurso rosista extremó la posición de los líderes indígenas quienes, ante la inminencia del poder estatal socavando su autoridad, se quebraron en llanto. En el contexto de 1839, por otro lado, la situación crítica del gobierno provincial abrió un resquicio por el cual 
pudieron colarse prácticas nativas de resistencia (interferencia en la comunicación interétnica, robos, amenaza de rebelión liderada por Callfiau). Fue necesario entonces poner en juego toda la pericia y diplomacia de Rosas para recomponer la situación y estabilizar las relaciones con las parcialidades "amigas".

Fue así como, ya pasado el levantamiento antirrosista de 1839 y cuando la situación empezó a componerse definitivamente, cansado y agobiado por los meses de aguda tensión, Bernardo Echevarría escribía a su par de Azul, Manuel Capdevila, "que esto de tener que contemporizar con los indios es una lidia del demonio". Teniendo en cuenta las consideraciones anteriores, ¿qué quedaría, al respecto, para los caciques?

Nos preguntamos en este punto qué proceso psico-sociológico habrá tenido lugar en ellos a la hora de enfrentarse con una realidad casi inentendible y (hasta cierto punto) impensable. ¿Qué mecanismos internos operaron para provocar su llanto? ¿Cómo se resolvió prácticamente la encrucijada en la que se hallaban las autoridades étnicas? Parafraseando al rey del Asteroide 325, ¿cómo pedir lo que no se puede dar? ¿Cómo entender ese "liderazgo en encrucijada"? Seguiremos indagando estos interrogantes en futuros avances de investigación. 